\title{
DRINKING WATER THROUGH RAINWATER HARVESTING: DEVELOPMENT AND PERFORMANCE EVALUATION OF A NOVEL FILTERATION SYSTEM
}

\author{
Manoj P. Samuel ${ }^{1}$, Abraham C. Mathew $^{2}$ \\ ${ }^{\text {I}}$ Principal Scientist, National Academy of Agricultural Research Management, Rajendranagar, Hyderabad - 500030, \\ India \\ ${ }^{2}$ Principal Scientist, Central Plantation Crops Research Institute, Kasaragod, Kerala, India- 671124
}

\begin{abstract}
For collection of rainwater for potable purposes, a vertical flow multimedia roof water filter was developed and tested for hydraulic efficiency and pollutant removal efficiency to meet drinking water standards. Along with sand and gravel, three forms of charcoals, which act as adsorbents, viz, (coconut) shell charcoal, wood charcoal and anthracite were tested as filter media. Along with these, three types of circular shaped screens made up of nylon, aluminium and non-woven coir-sisal fabric were also tested. Four different filling volume ratios, viz., 1:1:1, 3:2:1, 2:1:3 and 1:3:2 were employed. The quality of the inlet water was studies by collecting and analysing roof water samples from two sites each in Tamil Nadu and Kerala. The multimedia vertical filters were found to be effective in removing $T S, K$ and $\mathrm{PO}_{4}{ }^{2-}$, normalizing $\mathrm{pH}$ and reducing EC. It also showed good efficiency in removing nitrate. However, the removal percentage of $\mathrm{Fe}^{2+}, \mathrm{Na}^{+}$and $\mathrm{Ca}^{2+}$ were low, while that of $\mathrm{Mg}^{2+}$ showed -ve value. To compare different filter combinations, a new parameter, UPI (Universal Performance Index), which represents the weighted average of the hydraulic efficiency and quality improving efficiencies, giving extra weight to the latter, has been developed. Statistical analysis of UPI values for roof water filters showed that the proportion P3 (1:2:3), media M3 (anthracite) and screen S2 (aluminium mesh) were found to be the best. P1M3S2 (gravel-anthracite-sand in 1:1:1 proportion separated by aluminium meshes) emerged the best filter combination. The economic analysis of the developed filter system showed acceptable values for financial viability criteria including the Net Present Value, Internal Rate of Return and Benefit-Cost Ratio.
\end{abstract}

Keywords: Vertical filter, filter media, fabric screens, pollutant removal efficiency, hydraulic efficiency, economic analysis

\section{INTRODUCTION}

Water resources development remains the primary key to open up the vistas of sustainability of agriculture and the standard of living by way of industrialization or urbanization. Technological advancements and industrial growth warrant an addendum of existing water resources that are primarily exploited by the agricultural sector. Though rainwater harvesting helps to stabilize the supply-demand equilibrium for water, the quality of water as required for the multifacets of the water usage arena consistently undergo validity criteria for a fearless consumption. The quality criteria required for domestic purposes are quite different when compared to those for irrigation or industrial applications. The qualitative assessment of the water supplies at different stages inevitably would require a multi-stage and fool-proof embedding of effective filtration systems as part and parcel of all rainwater harvesting systems.

The rainwater input, whether it is roof water or storm water runoff, contains a lot of impurities and contaminants as it flows through uncleaned roof surfaces or contaminated/polluted land surfaces. The major pollutants in case of roof water are organic in nature, while that of storm runoff are mainly silt load, residues of pesticides/weedicides or fertilizers, organic materials, heavy metals and industrial chemicals. The quality of harvested water depends upon the end use; for example high standards have to be ensured for drinking water, but the quality can be low if the end use is for irrigation.

Roof water harvesting is essentially a system for collecting and storing rainwater from rooftops, mostly in tanks. Generally water is collected during the rainy days and stored in closed containers for use in dry spells. Usually, these systems are designed to support the drinking and cooking needs of the family. A typical roof water harvesting system comprises a roof, a guttering or water diversion arrangement and a storage tank. The store roof water can be used for lowquality domestic uses. General contaminants in the roof runoff include organic matter including dry leaves, faecal deposits from animals and birds, inert solids, trace amounts of some metals, and even complex organic compounds, which in turn provides essential nutrients for growth of bacteria. Forster (1996) argues that the factors such as type of roof material, antecedent dry period and surrounding environmental conditions are likely to influence concentrations of heavy metals in roof runoff. 
Rott and Mayer (2000) developed a system for testing filters as a part of the work surrounding the development of the German rainwater harvesting standard. Rasima et al. (2009) studied the efficacy of biofilm column and multimedia filtration systems which consist of granular activated carbon (GAC)-biofilm configured up-flow fluidized expanded bed (UFEB) reactor and slow down-flow packed sand bed reactor, in roof water harvesting systems. Some researchers used granular activated carbon (GAC) filtration as a pretreatment to microfiltration (MF) to remove the dissolved organic matter (DOC) in roof water (Areerachakul et al. , 2009).

Martinson and Thomas (2005) developed filters made up os stretched clothes and reported on its efficiency to remove particulates from roof run-off water. The tests showed that self-cleaning by using a sloping surface worked satisfactorily and that simple cloth filters had a comparable performance to sophisticated filters found in German rainwater harvesting systems. However, they suggested that the German test configuration did not adequately represent run-off water from the roof in tropical countries.

Though traditional methods of rain water collection are prevailing in some parts of the world, the system of harvesting, storing and reusing the harvested rainwater after quality enhancement with appropriate filtration mechanisms for various end uses viz., irrigation, drinking water, groundwater recharge etc. is comparatively a novel and innovative idea. In this context, a study was contemplated to develop an efficient filtration mechanism for roof water harvesting systems to enhance the quality of rainwater before it is diverted to storage tanks, especially for potable uses. The results of studies on performance evaluation of the developed vertical roof water filter consisting of fabric screens and filter media - gravel, charcoal and sand are presented in this paper.

\section{MATERIALS AND METHODS}

\subsection{Quality Parameters of Inlet Water}

The quality parameters of Direct Rainwater (DR), Roof Water (RW) and Storm runoff Water (SW) collected from both the sites were analysed for various physico-chemical parameters. Input water samples were collected in pre-cleaned polythene bottles with necessary precautions as per standard procedures (IS 3025, 1987). The water samples were further analysed for parameters such as $\mathrm{pH}$, electrical conductivity (EC), total dissolved solids (TDS), total solids (TS), total hardness (TH), total alkalinity (TA), calcium $\left(\mathrm{Ca}^{2+}\right)$, magnesium $\left(\mathrm{Mg}^{2+}\right)$, sodium $\left(\mathrm{Na}^{+}\right)$, potassium $\left(\mathrm{K}^{+}\right)$, phosphate $\left(\mathrm{PO}_{4}^{2-}\right)$, sulphate $\left(\mathrm{SO}_{4}^{2-}\right)$, iron $\left(\mathrm{Fe}^{2+}\right)$, chloride $\left(\mathrm{Cl}^{-}\right)$ and nitrate $\left(\mathrm{NO}_{3}{ }^{-}\right)$using standard methods and quality assurance procedures.

A vertical flow filtration mechanism was designed, developed and evaluated for filtering rainwater flowing down from roofs of buildings. The filter was cylindrical in shape and could be used as inlet filter before rainwater harvesting tank. The filter was designed with such an objective that the drinking water standards have to be met. A prototype of the filter device was fabricated and used for laboratory studies on hydraulic efficiency and quality improving efficiencies.

\subsection{Design and Fabrication}

A cylindrical column shaped filter made up of stainless steel was fabricated.

It resembled a real time prototype of column used for filtration studies (Fig.1)

The vertical filter was designed by using the first order kinetic $\left(\mathrm{k}-\mathrm{C}^{*}\right)$ model.

The process can be expressed algebraically as:

$$
\left(\mathrm{C}_{\text {out }}-\mathrm{C}^{*}\right) /\left(\mathrm{C}_{\mathrm{in}}-\mathrm{C}^{*}\right)=\mathrm{e}^{-\mathrm{kL} / \mathrm{q}}
$$

where,

$\mathrm{C}^{*}$ = background concentration $\left(\mathrm{mg} \mathrm{L}^{-1}\right)$

$\mathrm{C}_{\text {in }}=$ input concentration $\left(\mathrm{mg} \mathrm{L}^{-1}\right)$

$\mathrm{C}_{\text {out }}=$ output concentration $\left(\mathrm{mg} \mathrm{L}^{-1}\right)$

$\mathrm{k}=$ the decay rate constant $\left(\mathrm{L}\right.$ year $\left.{ }^{-1}\right)$.

$\mathrm{L}=$ water depth in filter, and

$\mathrm{q}=$ hydraulic loading (flow rate per surface area) of the treatment measure $\left(\mathrm{m}\right.$ year $\left.^{-1}\right)$

In this case, the $\mathrm{C}_{\text {in }}$ value was assumed based on the observed range of Total Solids (TS) in collected roof water. The $\mathrm{C}_{\text {out }}$ value was assumed based on the WHO (2008) and CPCB (2008) standards for drinking water.

So $\mathrm{C}_{\mathrm{in}}=580 \mathrm{mg} \mathrm{L}^{-1}$ and $\mathrm{C}_{\text {out }}=500 \mathrm{mg} \mathrm{L}^{-1}$

$\mathrm{k}=1000, \mathrm{C}^{*}=12(\mathrm{CRCCH}, 2009)$ and the depth of filter was taken as $0.5 \mathrm{~m}$.

So, $\mathrm{q}=3293.68 \mathrm{~m}$ year $^{-1}=9.024 \mathrm{~m} \mathrm{day}^{-1}$

Considering roof area of an average house as $100 \mathrm{~m}^{2}$, daily mean rainfall of 0.01237 and runoff coefficient of 0.86 (substituting impervious area as $90 \%$ in Eqn.).

Then,

$$
\mathrm{WQ}_{\mathrm{V}}=100 * 0.86 * 0.01237=1.0638 \mathrm{~m}^{3}
$$

Therefore,

Surface area of filter, $A_{f}=W_{V} / q=0.12 \mathrm{~m}^{2}$

So that the size of the filter was fixed as follows:

Diameter $=0.40 \mathrm{~m}$

Height $=0.50 \mathrm{~m}$

Thickness of the lid $=0.002 \mathrm{~m}$

Thickness of the basement $=0.02 \mathrm{~m}$

Therefore, Surface area of filter, $A_{f}=0.125 \mathrm{~m}^{2}$ 


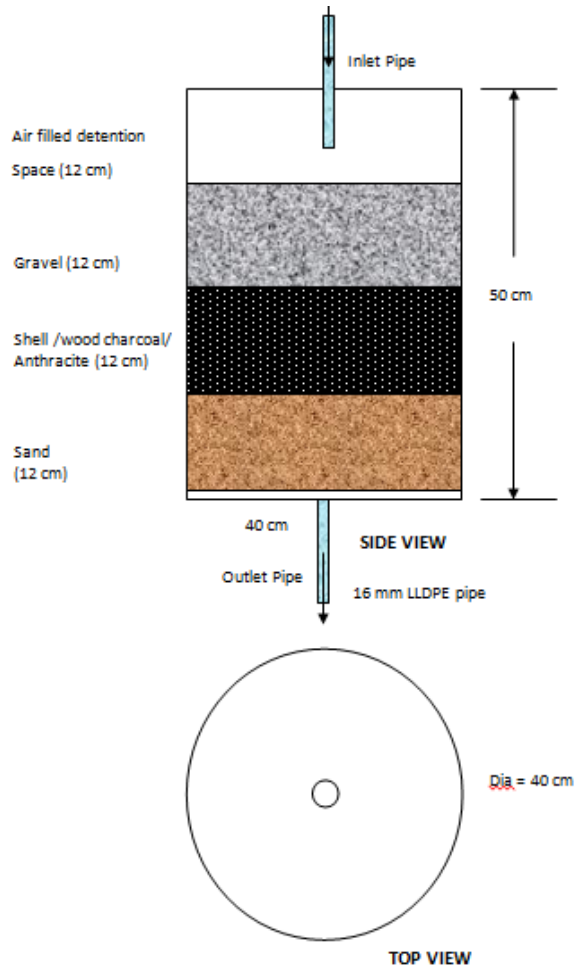

Fig. 1 Plan and elevation of roofwater filter with sand, charcoal and gravel (1:1:1 ratio)

\subsection{Experimental Setup}

Filer inlet was connected to pump and outlet to water sump by means of $16 \mathrm{~mm}$ size LLDPE pipes. Water was stored in a 500 litre capacity plastic tank (Sintex) and a $0.125 \mathrm{HP}$ selfpriming centrifugal pump was used to pump water from the sump towards the cylindrical filter (Fig.2). Rate of inflow was controlled by using a gate valve and pressure head of pumped water was measured using the precision pressure gauge, both attached to the inlet line. A u-tube manometer was fixed for a few experiments to measure hydraulic head of the outflow.

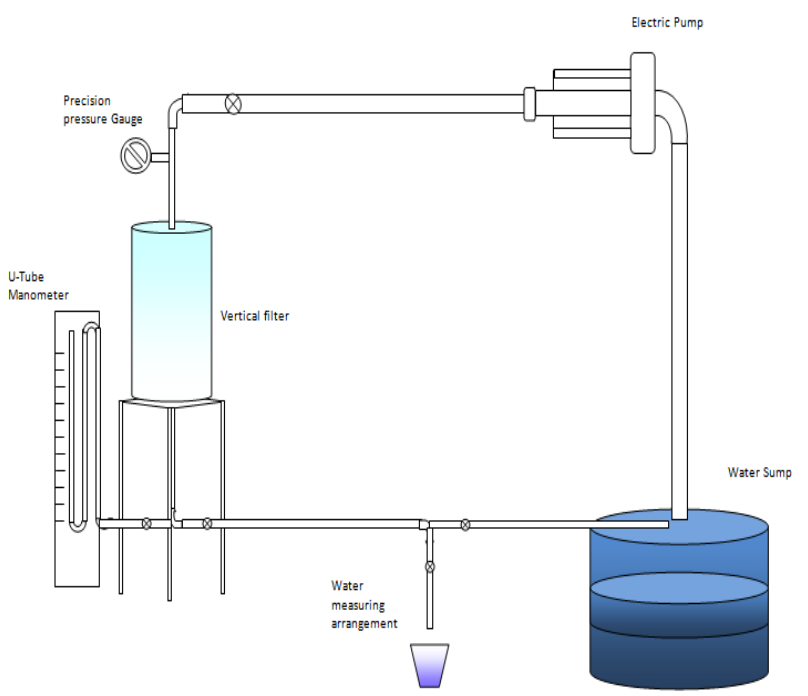

Fig.2. Experimental set-up of vertical roofwater filter

\subsection{Filter Media and Screens}

Different types of filter media including sand, gravel, biofibres and various adsorbents like wood, shell charcoals etc were put under study to find out the best filtration medium. To study the adsorption potential of each adsorbent and examine the results of solute concentration and time of reaction on adsorption, a series of batch and column experiments were carried out.

The filter under testing was a multi-media, vertical flow filter with three layers of filter materials separated by screens or without screens. Sand with mean particle size of $0.7 \mathrm{~mm}$ and uniformity coefficient 1.46 and crushed granite stones with average size of $20 \mathrm{~mm}$ were the generic media used and they were filled in the filter as the bottom and upper layers, respectively.

Three types of adsorbents, viz, (coconut) shell charcoal, wood charcoal and anthracite, were tested as the middle layer. The sand and gravel were procured from the local market while the shell charcoal and wood charcoal were obtained by burning coconut (Cocos Nucifera) shells and Prosopis (Prosopis Juliflora Linn) tree wood respectively. Apart from these, three types of circular shaped screens such as nylon, aluminum and non-woven coir-sisal fabric screens were also tested for its efficacy in removing pollutants in tandem with the filter media. The tests were also repeated with no screens.

Sand medium was filled first to the required height, and subsequently circular screen was inserted. The second layer is then filled to the required height, and again a screen was inserted and finally the upper layer was filled with gravel. The filter media were filled in four different volume ratios, viz., $1: 1: 1,3: 2: 1,2: 1: 3$ and $1: 3: 2$.

\subsection{Experimental Measurements and Analyses}

Experiment was carried out in completely randomized factorial design (factorial CRD) and each treatment was replicated three times. Difference between treatment means were tested for significance using standard analysis of variance tests. Subsequently Duncan's new multiple range test was employed for comparing the treatments.

\subsection{Hydraulic Efficiency (HE) and Quality Improving Efficiency (QIE)}

Hydraulic efficiency (HE) is calculated by obtaining the ratio of the quantity of outlet water by the inlet water through the filter (Martinson and Thomas 2003). The rate of inflow and outflow were measured in three replications, and subsequently the amounts of water flown through and spilled over the filter were calculated.

The filter effectiveness or chemical removal efficiency is the fraction of total chemical particulates removed by the filter (Hamoda et al. 2004). Similar method is employed for finding out the EC reducing efficiency and sediment removal efficiency. However since the $\mathrm{pH}$ has to be brought to the 
neutral value 7 by the filtration process, a new equation was formulated to find out the $\mathrm{pH}$ normalizing efficiency, as given below:

$\mathrm{pH}$ normalizing efficiency $=p\left[\frac{p H i-|7-\mathrm{pHo}|}{\mathrm{pHi}}\right] 100$

where, $\mathrm{pH}_{\mathrm{i}}=$ initial $\mathrm{pH}$ of water before filtration

$\mathrm{pH}_{\mathrm{o}}=\mathrm{pH}$ of water after filtration

(Samuel, et.al., 2014)

The term filter effectiveness or quality improving efficiency (QIE) was used in this paper as the mean of the removal efficiency values with respect to all analyzed physicochemical parameters and the $\mathrm{pH}$ normalizing efficiency.

\subsection{Universal Performance Index}

A terminology namely UPI (Universal Performance Index) is developed. It is the weighted average of the hydraulic efficiency and quality improving efficiencies, giving extra weight to the latter (Samuel, et.al., 2014).

The UPI can be computed as follows:

$$
\mathrm{UPI}=\frac{1}{2(n+1)}\left[\mathrm{HE}+2 * \sum_{i=1}^{i=n} Q I E i\right]
$$

where, HE = hydraulic efficiency

$\mathrm{QIE}_{\mathrm{i}}=$ quality improvement efficiency with respect to $\mathrm{i}^{\text {th }}$ parameter

$\mathrm{n}=$ total no of chemical parameters tested

The inlet and outlet pressure heads were recorded using precision pressure gauges fitted both in inlet and outlet pipes. The filtered water samples were collected as per standard methods in plastic containers and subjected to detailed water quality analysis for various chemical parameters using standard methods (APHA, AWWA and WEF 2005; Saxena 1994). The hydraulic efficiency, water quality improving efficiency and universal performance index (UPI) of various types of filter combinations were also computed.

Furthermore, economic analysis was carried out for the developed filter system. The B-C ratio, net present value (NPV) and internal rate of return (IRR) were computed using standard methodology.

\section{RESULTS AND DISCUSSION}

The objective of roof water filter is to provide potable quality water by filtering water flowing down from rooftops. In this study, a vertical flow filter was developed for the purpose. Quantitative and qualitative performance of the roof water vertical flow filter was carried out. The efficacy of three filter media combinations, viz., gravel- charcoal (coconut shell)sand, gravel- charcoal (wood)-sand and gravel-anthracitesand; three screens (non-woven sisal coir screen, aluminum mesh and nylon net) with no screens and four proportions $(1: 1: 1,3: 1: 2,1: 2: 3$ and $2: 3: 1)$ along with their 2-way and 3way interaction effects were studied.

\subsection{Hydraulic Efficiency}

Variation of hydraulic efficiency of the filter with respect to various proportions, media and screens were studied. It could be concluded that proportion P1 (1:1:1), media M3 (anthracite) and screen S2 (aluminum mesh) performed the superior based on its hydraulic efficiency. The filter combination P1M1S1 (gravel, charcoal (coconut shell) and sand in 1:1:1 proportion separated by non-woven sisal coir screens) showed the highest permeability apart from no screen combinations P1M1S4 and P3M2S4 (Fig.3). The hydraulic performance of the superior four filter combinations (with screens), which exhibited higher hydraulic efficiency, against the control (without screens) was also studied separately. The combination P1M1S4 (no screens) showed reasonably higher hydraulic efficiency even at higher flow rates. The filter systems with screens exhibited higher hydraulic efficiency at lower flow rates, which decreased sharply till the flow rates reached above $0.16 \mathrm{~L} \mathrm{~s}^{-1}$.

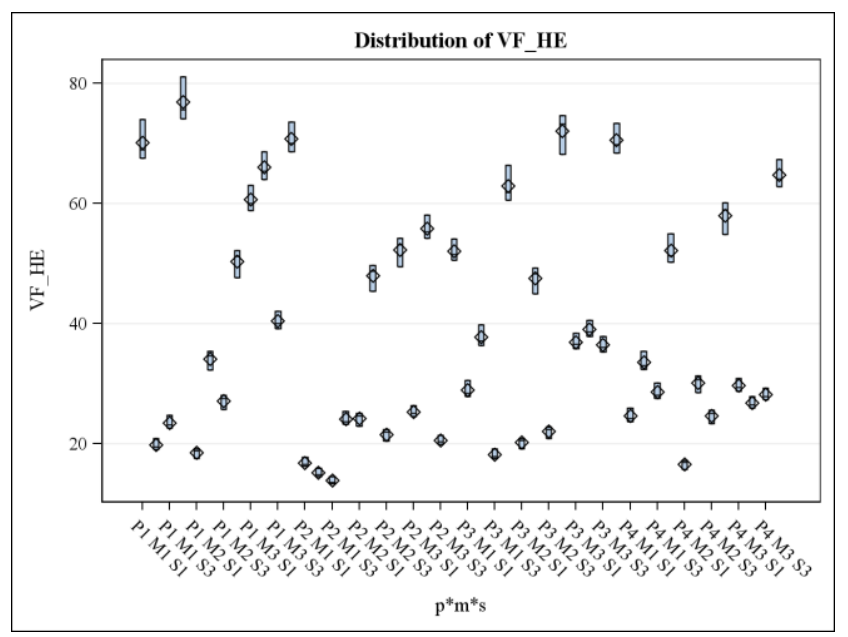

Fig.3. Hydraulic performance of various combinations of vertical flow roof water filters

The best filter combination with screens, P1M1S1 was subjected to further hydraulic testing including sensitivity analysis. It was observed that the media shell charcoal and anthracite performed well compared to the other media (wood charcoal) as far as hydraulic performance is concerned.

At very low flow rates, all media performed equally good, but the permeability of wood charcoal declined sharply and attained a constant rate when the flow rate was $>0.1 \mathrm{~L} \mathrm{~s}^{-1}$. The sharp decline might be due to blockage of filter screens by big blocks of wood charcoal in that particular case.

The coir-sisal non-woven fabric showed higher conductivity compared to other screens. It might be due to a larger number of micro-pores as well as openings/cracks in the filter screen. The proportion 1:1:1 showed higher permeability than other three proportions tested. The behaviour of gravel-charcoalsand filters with respect to its hydraulic properties resembled the results put forwarded by Martinson and Thomas (2005) based on a study of low-cost inlet filters for rainwater tanks. 
Hydraulic efficiency of the filter decreases non-linearly with increase in inflow volume. It is suggested from the results that water flowing through the filter would reach a maximum value and would not increase with further increase in inflow. The findings are similar to those of Hatt et al. (2009).

\subsection{Quality Improving Efficiencies}

The quality improving efficiencies of all 48 filter combinations were determined (Table. 1). The multi-layered, multi-media, vertical filters were found to be highly effective in removing TS, $\mathrm{K}^{+}$and $\mathrm{PO}_{4}{ }^{2-}$. The filter was excellent in normalizing the $\mathrm{pH}$ and reducing the EC. It also exhibited fairly good efficiency in removing $\mathrm{NO}_{3}{ }^{-}$.

Table 1 Average removal efficiencies of chemical parameters in roofwater by vertical flow filters

\begin{tabular}{|c|c|c|c|c|c|c|c|c|c|c|c|}
\hline \multicolumn{2}{|c|}{ Parameter } & pH & EC & TS & $\mathrm{Ca}^{2+}$ & $\mathbf{M g}^{2+}$ & $\mathbf{K}^{+}$ & $\mathrm{Na}^{+}$ & $\mathrm{Fe}^{+}$ & $\mathrm{PO}_{4}{ }^{2-}$ & $\mathrm{NO}_{3}^{-}$ \\
\hline \multicolumn{2}{|c|}{$\begin{array}{l}\text { Average } \\
\text { Removal } \\
\text { Efficiency }(\%)\end{array}$} & 93.17 & 68.47 & 95.69 & 0.66 & -1.77 & 75.56 & 14.34 & 17.36 & 98.12 & 44.12 \\
\hline \multicolumn{2}{|c|}{$\begin{array}{l}\text { Standard } \\
\text { Deviation }\end{array}$} & 1.755 & 12.4 & 4.53 & 11.90 & 7.376 & 10.45 & 19.53 & 49.94 & 1.25 & 2.22 \\
\hline \multirow[t]{2}{*}{ Range } & Max & 96.82 & 78.66 & 100 & 16.33 & 3.970 & 85.9 & 32.35 & 97.98 & 99.93 & 64.43 \\
\hline & Min & 88.64 & 34.45 & 87.03 & -31.6 & -20.78 & 53.85 & -35.29 & -74.24 & 95.66 & 23.81 \\
\hline
\end{tabular}

The removal percentage of iron $\left(\mathrm{Fe}^{2+}\right)$ and sodium $\left(\mathrm{Na}^{+}\right)$were comparatively low at $17.36 \%$ and $14.34 \%$ respectively. However, it was observed that the calcium $\left(\mathrm{Ca}^{2+}\right)$ removal was negligibly less, and the magnesium $\left(\mathrm{Mg}^{2+}\right)$ concentration was getting increased after filtration and this might be due to the effect of charcoal. Areerachakul et al. (2009) reported a reduction of nitrate and phosphate at $80 \%$ and $30 \%$, respectively, in the $10-\mathrm{cm}$ filter bed depth of granular activated carbon (GAC) filter with a submerged membrane system. However, Rasima et al. (2009), based on a study of multimedia filtration that consist of granular activated carbon -biofilm configured up-flow fluidized expanded bed (UFEB) reactor, reported $75.49 \%$ removal of iron $\left(\mathrm{Fe}^{2+}\right)$ and $51.76 \%$ to $82.98 \%$ removal of $\mathrm{NO}_{3}{ }^{-}$. In the present study, phosphate removal was recorded high $(98 \%)$ compared to nitrate (44 $\%)$. It could be concluded from the study that sand-charcoalgravel roof water filters were very good for removing chemicals such as $\mathrm{K}^{+}, \mathrm{Na}^{+}, \mathrm{PO}_{4}{ }^{2-}$ and $\mathrm{NO}_{3}{ }^{-}$, but they were not recommended for removing $\mathrm{Ca}^{2+}$ and $\mathrm{Mg}^{2+}$. It was also observed that the three significantly different activated carbon materials (shell charcoal, wood charcoal and anthracite) gave minor differences in adsorption.

The results of quality analysis were subjected to ANOVA and the best media, screen, proportion and combination were delineated based on Duncan's MRT method. It was found that the Media M3 (Gravel-Anthracite-Sand), Proportion P3 (1:2:3) and Screen S2 (Aluminium mesh) and the combination P4M3S2 (Gravel-Anthracite-Sand separated by Aluminium mesh in 2:3:1 proportion) as the best in terms of QIE.

The regression equations developed for sediment reduction capacity and overall chemical removal efficiency of the vertical filter are:

$\mathrm{S}_{\text {out }}=0.1282 \mathrm{~S}_{\text {in }}-0.2706$

$\left(\mathrm{R}^{2}=0.9646\right)$
$\mathrm{C}_{\text {out }}=0.8982 \mathrm{C}_{\text {in }}-5.3274$

$\left(\mathrm{R}^{2}=0.9358\right)$

where, $S_{\text {in }}$ and $S_{\text {out }}$ are TS load in inlet and outlet water respectively; and $C_{i n}$ and $C_{\text {out }}$ are the chemical concentrations in inlet and outlet water respectively.

\subsection{Universal Performance Index}

The UPI values of each filter combinations were computed and subjected to analysis of variance. The significance value comparing the groups is $<0.01$, so the null hypothesis, that there is no difference in the mean UPI values with the three major effects and their interactions, was rejected. The best media, screen, proportion and combination were delineated based on Duncan's MRT method.

All individual effects and their interactions were found to be significant at $1 \%$ level. Based on comparison of mean of the universal performance indices by Duncan's MRT method, the proportion P3 (1:2:3), media M3 (anthracite) and screen S2 (aluminium mesh) were found to be the best considering the overall ratings. As far as superiority in filter combination is concerned, P1M3S2 (gravel-anthracite-sand in 1:1:1 proportion separated by aluminium meshes) emerged the best.

Effect of flow rate on hydraulic efficiency for the P1M3S2 filter was observed to be higher at lower flow rates. The removal efficiency of the P1M3S2 filter for different parameters is depicted in Fig. 4. The filter was found very well in removing TS, $\mathrm{PO}_{4}{ }^{2-}, \mathrm{Fe}^{2+}, \mathrm{K}+$ and reducing EC. It was also good in normalizing the $\mathrm{pH}$. But removal efficiency of $\mathrm{Ca}^{2+}$ and $\mathrm{Na}^{+}$were too less, while that of $\mathrm{Mg}^{2+}$ was negative. 


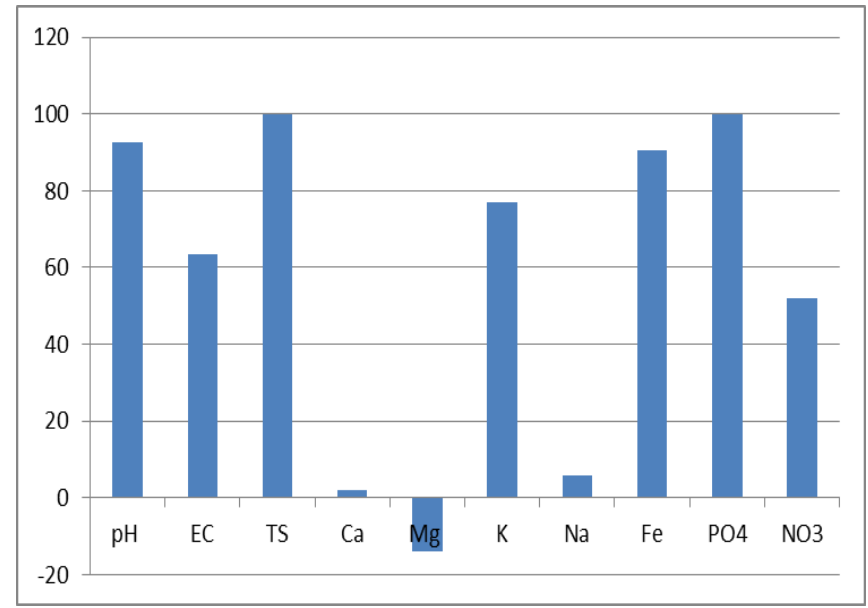

Fig.4. Removal efficiency of the P1M3S2 filter for different physico-chemical parameters

The effect of flow rate on hydraulic efficiency for the P1M3S2 filter was also studied and the result is shown in Figure 5.

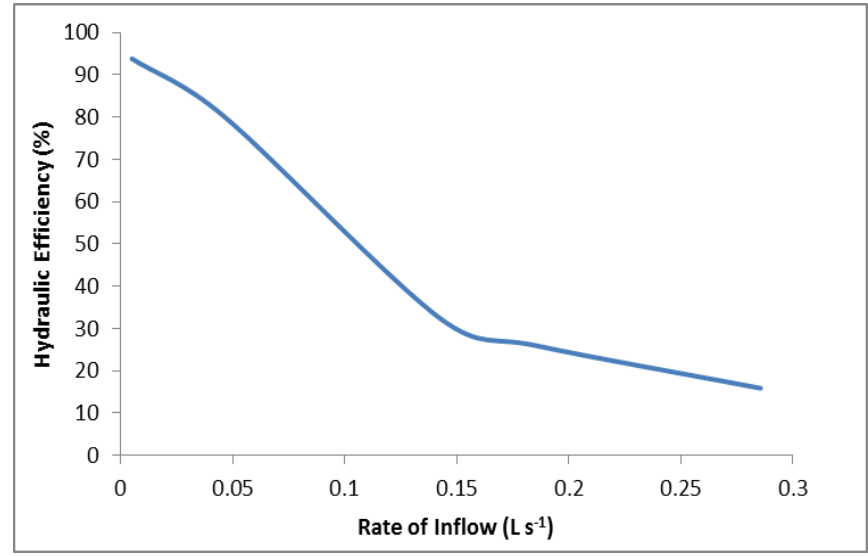

Fig.5. Effect of rate of inflow on hydraulic efficiency of P1M3S2 filter

\subsection{Economic Analysis}

With respect to the developed vertical roof water filter, the cost of filtration per kilo litre of water, net present value (NPV), internal rate of return (IRR) and benefit-cost ratio (BCR) f were calculated and shown in Table 2.

For all roof water filter, the NPV were positive and IRR were greater than the considered discount rate (taken as $14 \%$ ). Moreover, the $\mathrm{BC}$ ratio of all filters showed values greater than 1 , which is acceptable.

Table 2 The cost of filtration, NPV, IRR and BCR values of roof water filtration system

\begin{tabular}{|l|l|l|l|}
\hline $\begin{array}{l}\text { Cost of } \\
\text { filtration/m }\end{array} \mathbf{m}^{\mathbf{3}}$ (₹) & $\begin{array}{l}\text { NPV } \\
(₹)\end{array}$ & $\begin{array}{l}\text { IRR } \\
(\%)\end{array}$ & $\begin{array}{l}\text { BC } \\
\text { ratio }\end{array}$ \\
\hline 17.75 & 345.64 & 22 & 1.07 \\
\hline
\end{tabular}

The cost of filtration is merely Rs. 0.017 per litre of potable water, in spite of using high quality (potable standards) filtering using costly adsorbents such as charcoal or anthracite.
The developed filtration system is having low initial expenditure, zero power need, no maintenance cost and selfdependent operation. They are suitable for areas with less than normal/ normal rainfall so that rainwater could be harvested during monsoon days and store for use in lean season. No artificial or chemical materials are used in the developed filtration system and it was inferred that the natural fibre filter screens along with other filter media used in this study are essentially bio-degradable and environmentally friendly in nature.

\section{CONCLUSION}

A drinking water filtration mechanism was designed, developed and evaluated for roof water harvesting systems. Variation of hydraulic efficiency of the filter with respect to various proportions, media and screens were studied and proportion P1 (1:1:1), media M3 (anthracite) and screen S2 (Aluminium mesh) were found superior. Sensitivity of hydraulic efficiency with different media, screens and proportions were studied. Study on the relationship between pressure drop (head loss) and rate of flow through the filter revealed that the flow rate and head losses were linearly proportional to each other. By analysing the outlet water samples for the quality improvement efficiency, it was found that the roof water vertical filters were good in removing TS, $\mathrm{K}$ and $\mathrm{PO}_{4}{ }^{2-}$, normalizing $\mathrm{pH}$ and reducing EC. It is also efective in removing $\mathrm{NO}_{3}{ }^{-}$. However, the removal percentage of $\mathrm{Fe}^{2+}, \mathrm{Na}^{+}$and $\mathrm{Ca}^{2+}$ were low, while that of $\mathrm{Mg}^{2+}$ showed a negative value.

ANOVA of UPI values for roof water filters showed that all individual effects and their interactions were significant at $1 \%$ level. Based on the comparison of mean, the proportion P3 (1:2:3), media M3 (anthracite) and screen S2 (Aluminium mesh) were found to be the best. P1M3S2 (gravel-anthracitesand in 1:1:1 proportion separated by Aluminium meshes) emerged the best filter combination. The filter was found very well in removing TS, $\mathrm{PO}_{4}{ }^{2-}, \mathrm{Fe}^{2+}, \mathrm{K}^{+}$and reducing EC. But removal efficiency of $\mathrm{Ca}^{2+}$ and $\mathrm{Na}^{+}$were too less, while that of $\mathrm{Mg}^{2+}$ negative.

Economic analysis was conducted by deriving the values of various financial viability criteria like IRR, NPV and BCR. Further it was inferred that it a viable technology for farmers. The filter media in this study were cheap, environmentally compatible and biodegradable.

\section{REFERENCES}

[1] APHA, AWWA, \& WEF., (2005). "Standard Methods for Examination of Water and Wastewater", $21^{\text {st }}$ Edition. Washington D.C: American Public Health Association, USA.

[2] Areerachakul, N., Kitiphatmontree, M., Kandasamy, J., Kus, B., Duangduen, C., Pivsa-Art, S., et.al., (2009). Submerged membrane system with biofilter as a treatment to rainwater. Water, Air and Soil Pollution: Focus (2009), 9: 431-438. 
[3] Central Pollution Control Board (CPCB). 2008. Guidelines for Water Quality Monitoring. CPCB, Govt .of India, New Delhi.

[4] Cooperative Research Centre for Catchment Hydrology (CRCCH). 2009. MUSIC- E-Water User Manual. CRCCH, University of Canberra, Australia.

[5] Forster, J., (1996). "Patterns of roof runoff contamination and their potential implications on practice and regulation of treatment and local infiltration". Water Science and Technology, 33(6): 39-48.

[6] Hamoda, M. F., Al-Ghusain, I., and Al-Jasem, D. M., (2004). "Application of Granular Media Filtration in Wastewater Reclamation and Reuse". J. of Environ. Science and Health, Part A-Toxic/Hazardous Substances \& Environmental Engineering, 39(2): 385-395.

[7] Hatt, B. E., Fletcher, T. D., and Ana Deletic. (2009). "Hydrologic and pollutant removal performance of stormwater biofiltration systems at the field scale". $J$. of Hydrology, 365: 310-321.

[8] Martinson, D.B., and Thomas, T. (2003).” Improving water quality by design". In: Proceedings of $11^{\text {th }}$ International Rainwater Catchment Systems Conference, Texcoco, Mexico, August, 2003.

[9] Martinson, D.B., and Thomas, T. (2005). "Low cost inlet filters for rainwater tanks". In: Proceedings of $12^{\text {th }}$ International Rainwater Catchment Systems Conference, Nov 2005, New Delhi, India.

[10] Rasima Abdul id, Rakmi Abdul Rahman and Rasina Abdul Rasid. (2009). "Biofilm and multimedia filtration for rainwater treatment". J. of Sustainable Development, 2 (1): 196-199.

[11] Rott, U., and Meyer, C. (2000). "Attempts to examine rainwater filter systems to DIN 1998". In: Proceedings of Rainwater Use and Management in the International Context, Mannheim, Germany, 2000.

[12] Samuel, M.P., Senthilvel, S and Mathew, A.C. (2013). "Hydraulic and Pollutant Removal Performances of Environmentally Compatible Stormwater Filtration Systems". International Journal of Environmental Science and Technology (IJEST), Vol11, No.5, pp.1327-1342.

[13] Saxena, M. M. (1994). "Environmental Analysis Water, Soil and Air", $2^{\text {nd }}$ Edition. Bikaner, India: Agro Botanical Publishers, pp.4-86: 121-125.

[14] World Health Organization (WHO). 2008. Guidelines for Drinking-Water Quality [electronic resource]: Incorporating $1^{\text {st }}$ and $2^{\text {nd }}$ Agenda, Vol.1, Recommendations - 3rd ed. WHO, Geneva, www.who.int/water__sanitation_health/dwq/fulltext.pdf, Last accessed July 2010.

[15] Wong, T.H.F. (Ed). (2006). "Australian Runoff Quality: A Guide to Water Sensitive Urban Design”. Engineers Australia, Sydney, Australia. 